\title{
Geotechnical properties of a municipal water treatment sludge incorporating a coagulant
}

\author{
Brendan C. O'Kelly ${ }^{1}$ \\ BE, MEngSc, PhD, CEng, MICE, MIEI, PGeo, MIGI, FGS \\ Lecturer in Civil Engineering, \\ Department of Civil, Structural and Environmental Engineering, \\ Museum Building, Trinity College Dublin, Dublin 2, Ireland.
}

First submission: 26th June 2006.

Resubmitted: 27th July 2007.

\footnotetext{
${ }^{1}$ e-mail: bokelly@tcd.ie $\quad$ Tel. +35318962387
}

Fax. +35316773072 


\begin{abstract}
:
The geotechnical properties of municipal water-treatment sludge from an upland catchment are presented. The gelatinous sludge comprised flocs of mainly quartz, manganoan calcite and clay-sized organic solids, and incorporated an alum coagulant and an anionic polyelectrolyte. Standard Proctor compaction over the water content range of 160 to $780 \%$ yielded low bulk and dry density values of 0.95 to 1.10 and 0.12 to 0.36 tonne $/ \mathrm{m}^{3}$, respectively, in line with the low specific gravity of solids of 1.86 . The undrained shear strength and the water content were inversely related on a semi-log plot. The effective stress shear strength parameters were $c^{\prime}=0$ and $\phi^{\prime}=39^{\circ}$. The consolidation properties were studied using the oedometer, consolidometer and triaxial apparatus. The material was highly compressible with primary compression index $\left(\mathrm{C}_{\mathrm{c}}\right)$ values of 2.5 to 3.7 , and primary compression ratio $\left(\mathrm{C}_{\mathrm{c}}{ }^{*}\right)$ values of 0.20 to 0.28 . The majority of the strain response occurred due to primary consolidation although the material had a very low permeability (coefficient of permeability decreasing from $2 \times 10^{-9}$ to $5 \times 10^{-11} \mathrm{~m} / \mathrm{s}$ for $\sigma_{\mathrm{v}}{ }^{\prime}=3$ to $800 \mathrm{kPa}$ ). Secondary compression was minor with a mean secondary compression index $\left(\mathrm{C}_{\alpha \mathrm{e}}\right)$ of 0.15 , and $\mathrm{C}_{\alpha \mathrm{e}} / \mathrm{C}_{\mathrm{c}}=0.04$ to 0.06 .
\end{abstract}

Key words: Water treatment sludge, index, geotechnical properties, lagoon, land filling 


\section{Introduction}

Water-treatment sludge (WTS) is the residue of the filter backwash water, water softening, chemical coagulation, flocculation and settling processes in the treatment of potable water (Twort et al. 2000). The WTS material generally contains sand, silt, organic matter and micro organisms, chemicals (including lime, soda ash, caustic soda, carbon, iron or aluminium salts) and polyelectrolyte coagulant aids that are added during the treatment processes. The coagulants cause the impurities to aggregate into flocs that can be separated from the water, removing not only the impurities but also the chemical additives, and these processes have been described by Achari and Joshi (1995). Polyelectrolytes are synthetic, long-chained organic molecules (which may be cationic, anionic or non-ionic) and act as a binding agent to increase the inherent shear strength of the flocs. In general, WTS can be categorized as either alum sludge or lime sludge depending on the type of coagulant added.

Ever-increasing quantities of WTS are being produced due to increasing water usage by consumers; the implementation of more stringent regulations on the quality of potable water (for example, the Council of European Communities Drinking Water Directive 1998) and more stringent controls on the quality of wastewater discharges. At present, the principle means of disposal of WTS are thermal treatment and landfilling, either at dedicated sludge monofills, municipal landfills, or storage (often indefinite) in shallow or deep sludge lagoons. The WTS material may be placed at dedicated sludge deposition areas in a municipal landfill (for example, in cases where the municipal waste has been bailed) or alternatively the material may be placed in continuous thin layers, and mixed and scarified insitu. Unlike sewage sludge, WTS is less likely to contain significant concentrations of dangerous substances. However, WTS is less amenable to land spreading or for use in agriculture as a fertilizer.

The sludge must be adequately dewatered to engineer, for example its efficient landfill disposal considering handling and trafficability requirements for machine plant, field compaction, and the provision of an adequate factor of safety against slope instability at the monofill or municipal landfill site. The WTS material is dewatered at the treatment works by mechanical means (belt filter press, recessed-plate filter press, or centrifuge dewatering systems (Metcalf and Eddy 1991)) and/or by air drying the material onsite in shallow drying beds or sludge lagoons. However, it generally proves most difficult to dewater WTS, including by mechanical means. Alum in WTS is predominately amorphous $\mathrm{Al}(\mathrm{OH})_{3}$ which is strongly hydrated and its exceptionally high affinity for water makes WTS most difficult to dewater (Wang et al. 1992).

The WTS material is soil-like, and as such, its behaviour in a sludge lagoon, sludge monofill, or dedicated sludge deposition area at a municipal landfill can be modelled using soil mechanics theory. Standard geotechnical laboratory tests were conducted to BS1377 (1990a) in order to determine the geotechnical and drying properties of the material pertinent to its safe and efficient storage (pending removal from the treatment works) and its offsite disposal. The data are also pertinent to its co-disposal at municipal landfills but the affects of other important factors such as the mode of placement of the WTS material (including layer thickness, mixing and scarifying after placement) must also be considered for the composite waste. For example, Geuzens and Dieltjens (1991) reported that depending on the relative volumes of sludge for disposal, the WTS material in the Belgian Flemish region was either placed in municipal landfills as packages or layers of up to $2 \mathrm{~m}$ in thickness, or as thin layers (which leads to a thorough mixing with the surrounding waste). 
The WTS material under study in this paper was obtained from the Ballymore Eustace water treatment works (County Kildare, Ireland) which in 2005 produced 250 mega litres of potable water per day for a substantial part of the greater Dublin area, Ireland. In total, about 1200 tonnes/year of the wet WTS material was produced as a residual at the Ballymore Eustace works. The geotechnical behaviour of WTS depends on the source of the raw water, and to some extent, on the geology and hydrogeology of the catchment area. The raw water was collected in the County Wicklow and Dublin mountains (upland catchment of peat over granite bedrock); stored in the Poulaphouca reservoir, and treated at the nearby Ballymore Eustace works. The slurry residue from the different physio-chemical treatment processes were mixed in a balancing tank at the Ballymore Eustace works and subsequently dewatered by mechanical means. A primary dose of alum (the most commonly used coagulant in water treatment) was added to the sludge in the thickening tanks, along with an anionic polyelectrolyte coagulant aid, to encourage the flocculation of the solid particles. After storage in a holding tank, a second dose of chemicals was added to the material before its water content was reduced to about 330\% using a recessed-plate, filter press dewatering system (Metcalf and Eddy 1991). The sludge leachate was yellowish-green in colour.

In this paper, the amount of water in the material was quantified using the geotechnical definition of water content $(\mathrm{w})$, defined as the ratio of the mass of the pore water to the mass of the dry solids, expressed as a percentage. The solids content (SC) value, used in watertreatment literature, is defined as the percentage of the dry solid mass to the bulk sludge mass, and is related to the percentage water content value using eq. [1]. The water content was determined using the oven-drying method. The mass of the dry solids corresponded to the mass achieved after drying the test specimen in an oven at a temperature of $105 \pm 5^{\circ} \mathrm{C}$ for a period of 24 hours.

$$
\mathrm{SC}=\frac{100}{1+\left(\frac{\mathrm{w}}{100}\right)}
$$

The geotechnical properties of some alum and iron-coagulant WTS materials have been report by Geuzens and Dieltjens (1991); Lim et al. (2002); Novak and Calkins (1975); Raghu and Hsieh (1986); and Wang et al. (1992). In particular, the permeability behaviour of an alum WTS was reported by Wang and Tseng (1993).

\section{Index and physical properties}

Some geotechnical properties of the black slurry material direct from the Ballymore Eustace treatment works are listed in Table 1. The term "slurry" refers to WTS material at water contents greater than the liquid limit value, and had a low bulk density of about 1.04 tonne $/ \mathrm{m}^{3}$. The material was gelatinous and thixotropic in nature, comprising mainly flocs of clay-sized solids and had a soapy texture. The material had significant plasticity, with liquid and plastic limit values of 490 and $240 \%$, respectively. Similar values of 550 and $239 \%$, respectively, were reported by Wang et al. (1992) for an alum WTS.

Ignition of the powdered, oven-dried material in a muffle furnace at $440^{\circ} \mathrm{C}$ yielded a loss in dry mass on ignition (LOI) value of $57 \%$ (an indication of its gravimetric solid organic content). Organic matter in soil is often responsible for high plasticity, high shrinkage, high compressibility and low permeability (Mitchell and Soga, 2005). The very high LOI value is 
consistent with the geology and hydrogeology of the catchment area (peat over granite bedrock). The residual ash material (comprising black, sand-like grains) from the LOI test was non-plastic. The extremely high plasticity (plasticity index value of $250 \%$ ) occurred due to: (i) the exceptionally high affinity of alum for water; (ii) the destabilisation of the dispersed solids during the chemical coagulation process (Wang et al. 1992); and (iii) the very high solid organic content. The WTS material was classified as high plasticity organic clay. However, the material plotted below the A-line on the Unified Soil Classification chart and it is hypothesised that this was due to its high organic content.

The specific gravity of solids $\left(\mathrm{G}_{\mathrm{s}}\right)$ value was measured using the small pycnometer method (BS1377 1990b). Kerosene was used instead of distilled water as the fluid in the pycnometer bottles. The measured $\mathrm{G}_{\mathrm{s}}$ value of 1.86 was similar to that reported for an alum WTS $\left(\mathrm{G}_{\mathrm{s}}=\right.$ 1.9) by Raghu and Hsieh (1986). Both of these values are low, however, in comparison with that of mineral soils which generally have values in the range of $\mathrm{G}_{\mathrm{s}}=2.5$ to 2.7. X-ray diffraction analysis of the wet and dry WTS material indicated that the inorganic clay fraction comprised quartz and manganoan calcite $\left((\mathrm{Ca}, \mathrm{Mg}) \mathrm{CO}_{3}\right)$, and there was no evidence of other crystalline phases. The chemical additives of alum and polyelectrolytes in the WTS material did not feature in the X-ray analysis since alum, comprising between 5 and $15 \%$ by dry weight of the WTS material (Wang et al. 1992), is predominately amorphous $\mathrm{Al}(\mathrm{OH})_{3}$ (mineral is disordered and without definable crystalline structure) and the polyelectrolytes are synthetic organic molecules. The $\mathrm{pH}$ of 8.6 for the slurry material ( $\mathrm{SC}=0.9$ to $2.3 \%$ ) was measured using an electrometric method. Further details of the physio-chemical properties of the Ballymore Eustace WTS have been reported by Yang et al. (2006).

The shrinkage, swelling and adhesion properties of the WTS were also studied. A brittle, crystalline precipitate was produced on oven drying the material to constant mass at $105^{\circ} \mathrm{C}$. The dry solid material was hydroscopic in nature (arising from exceptionally high affinity of alum for water) and shattered easily on reabsorbing moisture from the atmosphere. The maximum volumetric expansion that occurred on full re-saturation of the oven-dried material was measured using the free swell test (Gibbs and Holtz 1956). A $10 \mathrm{ml}$ volume of the powdered, oven-dried material was pluviated into $50 \mathrm{ml}$ of distilled water that was contained in a graduated cylinder. The free swell value of 35\% (calculated as the percentage increase in the volume of the dry solids) indicated significant swelling potential and was consistent with the extremely high plasticity of the wet material.

The linear shrinkage value of $47 \%$ was calculated as the percentage reduction in the length of a bar of wet WTS that had been fully dried from the liquid limit condition. The lowest water content (adhesion limit) at which the material adhered to a clean dry spatula that had been lightly drawn over the surface of a moist sludge pat was about $240 \%$ water content. Handling, transportation and landfilling of the WTS material will prove more difficult at water content values above the adhesion limit due, in part, to the tendency of the material to adhere to machine plant.

\section{Standard proctor compaction}

Standard Proctor compaction tests were conducted on material that had been air-dried from the slurry state. The water content was controlled by allowing thin layers of the wet material to air dry naturally over different periods at ambient temperature. The material dried slowly due to the exceptionally high affinity of alum for water and the high organic content of the 
material. The test material was thoroughly mixed and disaggregated to pass through the 20$\mathrm{mm}$ sieve size before standard Proctor compaction was conducted using a one-litre compaction mould. The bulk and dry density values of 0.95 to 1.10 and 0.12 to 0.36 tonne $/ \mathrm{m}^{3}$, respectively, measured over the water content range of 160 to $780 \%$ were low overall (Fig. 1) but were in line with the low $\mathrm{G}_{\mathrm{s}}$ value. The zero air-void curve plotted in Fig. 1 shows the density values of the fully saturated material which were calculated on the basis of the measured $\mathrm{G}_{\mathrm{s}}$ value. The actual air voids content for standard Proctor compacted material in excess of $260 \%$ water content was typically between 2 and $3 \%$. The agglomerates were brittle, almost crystalline in structure, granulating under the impact of the compaction rammer below $260 \%$ water content with the material crushing to a dust below $180 \%$ water content. Since alum is a precipitating agent, significant irreversible decreases in plasticity occurred when the material was dried; characteristic of some soils rich in oxides and hydroxides of aluminium (Mitchell and Soga, 2005).

The dry density versus water content curve for standard Proctor compaction was relatively flat within the test range of 160 to $780 \%$ water content ( $\mathrm{SC}=11$ to $38 \%)$. The dry density was found to decrease with increasing water content since pore water occupies an increasing proportion of the sludge volume. The optimum value of the water content corresponding to the maximum compacted dry density does not occur with the test range, although it is most likely below $160 \%$ water content. Similar compaction behaviour has been reported for two alum WTS by Wang et al. (1992).

The density values achieved by allowing the standard Proctor compacted material to slowly air-dry were also determined. This data are pertinent to the natural air-drying of WTS contained in drying beds and sludge lagoons; or material that has been standard Proctor compacted in dedicated monofills. After a period of air drying, the density of the standard Proctor compacted test specimens (initially $38.0 \mathrm{~mm}$ in diameter and $76.0 \mathrm{~mm}$ in height) were calculated from the recorded specimen mass and volume. The bulk and dry density values for the air-dried specimens were consistently higher than those achieved by standard Proctor compaction alone below about $300 \%$ water content (Fig. 1).

\section{Shear strength}

\subsection{Undrained shear strength properties}

The undrained shear strength of the WTS material was measured as a function of its water content. The data are pertinent to the handling of the material, trafficability by machine plant, and achieving an adequate factor of safety against short-term slope instability of sludge deposits. Unconsolidated-undrained (UU) triaxial compression tests were conducted on specimens (38.0 $\mathrm{mm}$ in diameter and $76.0 \mathrm{~mm}$ in height) prepared from material that had been standard Proctor compacted in the one-litre compaction mould ( 3 to $5 \%$ air voids). Some of the triaxial specimens were allowed to slowly air-dry at ambient laboratory temperature prior to shearing. Drying periods of one, two or four days caused reductions of typically 25, 35 and $50 \%$ water content, and the densities of these specimens are plotted in Fig. 1. This simulated the gain in shear strength experienced by material compacted in a sludge monofill or used as daily cover for a municipal landfill due to natural air-drying and curing (thixotropic hardening) processes. 
A cell confining pressure of $100 \mathrm{kPa}$ was applied and the specimens were then sheared at $2 \%$ axial strain/min. The standard correction for the restraining effects on the barrelling type of specimen deformation caused by the enclosing rubber membrane was applied to the maximum deviator stress value in accordance with BS1377 (1990d). Some typical deviator stress versus strain plots corresponding to a range of water content values are shown in Fig. 2 . The undrained shear strength was fully mobilized at less than about $8 \%$ axial strain; sign ificantly less than the limiting $20 \%$ strain generally associated with high plasticity organic clays. The data of undrained shear strength $\left(\mathrm{s}_{\mathrm{u}}\right)$ versus water content (w, expressed as a percentage) for the partially saturated material (Fig. 3) indicates an inverse relationship on a semi-log plot given by eq. [2]:
$\log \mathrm{s}_{\mathrm{u}}=3.8-0.007 \mathrm{w}$
$\left(\mathrm{kN} / \mathrm{m}^{2}\right)$
(for $\mathrm{w}<480 \%$ )

\subsection{Effective stress shear strength parameters}

The effective stress shear strength parameters, used in determining the factor of safety against instability of the landfill slopes for the intermediate and long-term conditions, were measured using the consolidated-undrained (CU) triaxial compression test, and with measurement of the pore water pressure response. Four specimens labelled A to D (each $38.0 \mathrm{~mm}$ in diameter and $76.0 \mathrm{~mm}$ in height) were prepared from a fully saturated sludge cake (152 $\mathrm{mm}$ in diameter and $90 \mathrm{~mm}$ in thickness) that had been uniformly consolidated in a slurry consolidometer to about $475 \%$ water content ( $\mathrm{SC} \cong 17 \%$ ) under an applied vertical stress of $30 \mathrm{kPa}$. A target back pressure $\left(\mathrm{u}_{\mathrm{b}}\right)$ of $200 \mathrm{kPa}$ was applied by incrementing in steps the cell confining pressure and the back pressure values to ensured that the triaxial specimens remained in a fully saturated condition; confirmed by measuring a Skempton (1954) pore pressure coefficient B $\geq 0.98$. The triaxial specimens were isotropically consolidated and allowed to drain radially (via filter paper side drains fitted over the specimen wall surface) and from both ends over a period of 24 hours. Mean effective confining stresses $\left(\sigma_{3}{ }^{\prime}\right)$ of 30, 60, 120 and $150 \mathrm{kPa}$ were achieved (Fig. $4 a$ ). The water content values of the consolidated specimens were 405, 350, 310 and $300 \%$ in order of increasing confining pressures.

During a trial test, a CU triaxial specimen failed at about $2 \%$ axial strain (shear rate $7 \times 10^{-4} \%$ axial strain/min) instead of the limiting $20 \%$ strain condition more generally associated with high plasticity, normally consolidated, organic clays. The distinctive constitutive behaviour is hypothesises to occur due to the chemical additives of alum and polyelectrolyte in the WTS material. The shear resistance is enhanced firstly by the aggregation of the clay particles into larger-sized flocs and the deactivation of water by the alum coagulant; and secondly and more importantly by the binding together of these flocs into clusters by the long-chained polyelectrolyte molecules.

Hence, specimens A to D were sheared even slowly at a rate of $6 \times 10^{-5} \%$ axial strain $/ \mathrm{min}$ (determined from curve-fitting analysis of the consolidation data in accordance with BS1377 (1990c)) such that all of the pore water pressures would had equilibrated throughout the specimens by $2 \%$ axial strain. As it transpired, specimen $\mathrm{C}$ did not fail until about $3 \%$ strain, and specimen D only yielded plastically at 4 to $5 \%$ strain and failed at about $10 \%$ strain (Fig. $4 b$ ). A higher strain rate could have been used in shearing these specimens. Nevertheless, the selected strain rate of $6 \times 10^{-5} \%$ axial strain/min guaranteed that all of the pore water pressures had equilibrated throughout the specimens at failure. The measured deviator stress $\left(\sigma_{1}-\sigma_{3}\right)$ and the pore water pressure responses are shown in Figs. $4 b$ and $4 c$. The standard corrections 
for the reinforcing effects on the barrelling type of specimen deformation due to the side drain and enclosing rubber membrane were applied to the maximum deviator stress accordance with BS1377 (1990d).

The effective stress path plots of $t=1 / 2\left(\sigma_{1}-\sigma_{3}\right)$ versus $s^{\prime}=1 / 2\left(\sigma_{1}^{\prime}+\sigma_{3}^{\prime}\right)$, shown in Fig. $4 d$, are characteristic of normally consolidated clay. The failure line of best-fit was drawn passing through the origin (effective cohesion c', value of zero) and the stress points corresponding to failure of the different specimen. The value of the effective angle of shearing resistance $\phi^{\prime}=$ $39^{\circ}$ was calculated using eq. [3]:

$\operatorname{Sin} \phi^{\prime}=$ Tan $\alpha^{\prime}$

where $\alpha$ ' is the slope angle of the failure line to the horizontal s' axis (Fig. $4 d$ ).

Given the high plasticity index value of $250 \%$, the measured $\phi^{\prime}=39^{\circ}$ is surprisingly high compared with that associated with highly plastic clay minerals (for example, montmorillonite with $\phi^{\prime}=5$ to $10^{\circ}$ reported by Mitchell and Soga (2005)). However, it is not unusual for some highly plastic, waste materials to have such a high $\phi^{\prime}$ value. For example, Wang et al. (1992) reported $\phi^{\prime}=42$ to $44^{\circ}$ for alum and iron WTS materials. O'Kelly (2006) reported $\phi^{\prime}=32$ to $37^{\circ}$ for municipal sewage sludge material ( $\mathrm{LOI}=55$ to $70 \%$ ), also measured in CU triaxial compression tests. These sewage sludge and alum and iron WTS materials had also been chemically conditioned with polyelectrolyte additives at the treatment works to aggregate and increase the inherent shear strength of the constituent flocs.

The ratio of the shear strength $\left(\mathrm{s}_{\mathrm{u}}\right)$ to the mean effective confining pressure $\left(\sigma^{\prime} \mathrm{c}\right)$ at failure ranged between 1.6 and 2.0. This range is higher than the ratio of 1.2 predicted by Wroth and Houlsby (1985) for a normally consolidated soil of similar plasticity characteristics; again explained due to the enhancement in the shear resistance by the chemical additives. The value at failure of the Skempton (1954) pore pressure coefficient $A_{f}$ (eq. [4]) ranged between 0.7 and 1.0, which is consistent with $\mathrm{A}_{\mathrm{f}}=0.75$ to 0.79 reported for alum and iron WTS by Wang et al. (1992); and within the range of 0.5 to 1.0 associated with normally consolidated clays. All other factors being equal, the shear resistance should increase linearly with the logarithm of the strain rate (Mitchell and Soga 2005). However, the shear strength data from the UU and $\mathrm{CU}$ triaxial compression tests shown in Fig. 3 were in good agreement, plotting along the same line against water content, although it is hypothesised that this is just an artefact of the test conditions.

$$
A_{f}=\frac{u_{e}-u_{o}}{\left(\sigma_{1}-\sigma_{3}\right)}
$$

where $\mathrm{u}_{\mathrm{e}}$ and $\mathrm{u}_{\mathrm{o}}$ are the pore water pressures values measured during the shearing stage and at the end of the consolidation stage, respectively; and $\left(\sigma_{1}-\sigma_{3}\right)$ is the deviator stress.

\section{Dewatering and consolidation properties}

\subsection{Consolidation tests}

The consolidation properties of the WTS material were determined using the oedometer, consolidometer and triaxial apparatus (Table 2$)$ over a wide range of effective stress $\left(\sigma_{v}=3\right.$ to 
$800 \mathrm{kPa}$ ). This range covered the diverse stress regimes experienced in dewatering, storing and landfilling the material: namely, low levels of effective stress in a sludge lagoon; low to medium levels of effective stress for the landfilled material; and medium to very high levels in mechanically dewatering the material at the treatment works. For example, the recessedplate, filter press system consolidates the wet WTS under confining pressures of typically either 700 or $1500 \mathrm{kPa}$ (generally the latter for alum WTS) depending on the sludge type and level of dewatering required.

The isotropic triaxial consolidation tests, which were conducted in the course of measuring the effective stress strength parameters, were described earlier in section 4.2. The multiple increment, maintained-load oedometer and consolidometer tests, conducted in accordance with BS1377 (1990c), are described below. The consolidation tests were conducted on freshly remoulded material since Wang and Tseng (1993) have shown that curing periods of up to two months for an alum WTS material had an insignificant effect on its permeability properties.

\subsection{Oedometer tests}

The oedometer specimens $\mathrm{E}$ and $\mathrm{F}$ were prepared by pressing the remoulded WTS material into the consolidation rings using a spatula. The test material had been prepared by adding distilled water to the pressed sludge cake from the treatment works; thoroughly remoulding and allowing the mixture ( $\mathrm{w} \cong 775 \%$ ) to equilibrate over a standing period of one week.

Specimen E (76.2 $\mathrm{mm}$ in diameter and initially $14.8 \mathrm{~mm}$ in height) was only allowed to drain from its top end, with continuous measurement of its pore water pressure response via a saturated porous disc located in the base of the consolidation cup (Fig. 5). Specimen F (76.2 $\mathrm{mm}$ in diameter and $30.0 \mathrm{~mm}$ in height) had porous stones in contact with both of its ends in order to allow two-way drainage of the specimen to atmosphere, but without measurement of its pore water pressure response. Each load stage was of two-day duration and the applied vertical stress $\left(\sigma_{\mathrm{v}}\right)$ was doubled in moving from one load stage to the next, over the applied stress range of 3 to $800 \mathrm{kPa}$.

The oedometer data for specimens $\mathrm{E}$ and $\mathrm{F}$ are presented as cumulative strain versus logarithm of time and square-root of time plots in Fig. 6. In accordance with Terzaghi consolidation theory (1943), the consolidation responses of specimens $\mathrm{E}$ and $\mathrm{F}$ (which had equivalent effective drainage lengths) were broadly similar. As expected, the proportion of secondary to primary consolidation was marginally greater for the thinner of the two specimens with cumulative strains of 57.3 and $54.7 \%$ (specimens $\mathrm{E}$ and $\mathrm{F}$, respectively) achieved for $\sigma_{\mathrm{v}}=800 \mathrm{kPa}$. The normalized excess pore water pressure response measured at the base of specimen E is shown in Fig. 7. Small changes in ambient laboratory temperature over the test duration caused some slight cyclic variations in the readings of the pressure transducer which are reflected in these data.

\subsection{Consolidometer tests}

Specimen $\mathrm{G}$ was prepared by placing the slurry material from the treatment works $(\mathrm{w} \cong$ $625 \%$ ) in a consolidometer press and compacting by rodding the material (air voids content of $5.3 \%$ ). The specimen (initially $152 \mathrm{~mm}$ in diameter and $139 \mathrm{~mm}$ in height) was compressed 
under applied stresses of $\sigma_{\mathrm{v}}=10,16$ and $30 \mathrm{kPa}$, and with two-way drainage of the specimen to atmosphere. Each of these load stages was of 7 days duration. The cumulative strains versus logarithm of time plots are presented in Fig. 8. Water content tests were conducted over the specimen thickness of $90 \mathrm{~mm}$ at the end of the consolidometer test. The final water content value of $475 \%$ ( $\mathrm{SC} \cong 17 \%$ ) was uniform throughout the specimen indicating that a uniform degree of consolidation had been achieved.

\subsection{Compressibility and consolidation properties}

The applied stress-strain-time data from the consolidation tests are presented in the form of void ratio-logarithm effective stress $\left(\mathrm{e}-\log \sigma_{\mathrm{v}}{ }^{\prime}\right)$ plots in Fig. 9. The compressibility of the WTS material was quantified in terms of the primary compression index $\mathrm{C}_{c}$, defined as the gradient of the $\mathrm{e}-\log \sigma_{\mathrm{v}}{ }^{\prime}$ curve, and its value reduced marginally with increasing effective stress. The material is highly compressible with high $\mathrm{C}_{\mathrm{c}}$ values of 3.7 to 2.5 for $\sigma_{\mathrm{v}}{ }^{\prime}=3$ to 800 $\mathrm{kPa}$. Wang et al. (1992) also reported high $\mathrm{C}_{\mathrm{c}}$ values of 5.3 and 6.7 for alum WTS materials. The $C_{c}$ values of most natural clays are less than 1.0 , and generally less that 0.5 . The values of the primary compression ratio $\mathrm{C}_{\mathrm{c}} *$ (calculated using eq. [5]) were 0.20 and 0.28 ; these values corresponding to load stage durations of two and six days, respectively.

$$
\mathrm{C}_{\mathrm{c}} *=\frac{\mathrm{C}_{\mathrm{c}}}{1+\mathrm{e}_{\mathrm{o}}}
$$

where $e_{o}$ is the initial void ratio.

The data curves exhibited the characteristic shape of the theoretical curves given by Terzaghi consolidation theory (1943). The initial specimen compression at the start of each load step was negligible indicating that both specimens were in a fully saturated state. The relative proportions and rates of the primary consolidation and secondary compression phases in the measured strain-time responses were readily differentiated using standard curve-fitting analysis. The primary and secondary compression phases were also readily differentiated from analysis of the measured degree of consolidation achieved for specimen E (Fig. 10). The ratio of the initial, primary and secondary phases (expressed as a percentage of the total compression recorded during a given load stage) were in order typically 1,85 and $14 \%$, which confirmed that the majority of the strain response occurred as a result of primary consolidation.

The average degree of consolidation achieved for specimen $\mathrm{E}$ was calculated from its measured pore water pressure response. It was assumed that the distribution of the excess pore water pressure over the specimen height was defined by a parabola (Fig. 11). The vertex of the parabola was defined by the pore water pressure value measured at the specimen base $\left(\mathrm{u}_{\mathrm{b}}\right)$, which reduced in value with elapsed time. The average degree of consolidation $(\bar{U})$, expressed as a percentage, was calculated by comparing the size of the areas enclosed by the parabola at any given time relative to that enclosed by the initial pore water pressure response:

$\overline{\mathrm{U}}=\frac{\Delta \sigma_{\mathrm{v}}-2 / 3 \mathrm{u}_{\mathrm{b}}}{\Delta \sigma_{\mathrm{v}}} \quad(\mathrm{x} 100)$

The rate of primary consolidation was quantified in terms of the coefficient of primary consolidation, $\mathrm{c}_{\mathrm{v}}$. Although low, the measured $\mathrm{c}_{\mathrm{v}}$ values of between 0.1 and $0.8 \mathrm{~m}^{2} /$ year (Fig. 
12) are consistent with that of high plasticity clays, with $c_{v}$ increasing marginally with increasing effective stress. In general, the $\mathrm{c}_{\mathrm{v}}$ values that were derived using the logarithm of time (Casagrande and Fadum 1940) and square-root of time (Taylor 1942) curve-fitting techniques, and the values based on the average degree of consolidation measurements, were in good agreement.

The coefficient of permeability (k) values were calculated using eq. [7]. When plotted using a $\log -\log$ scale (Fig. 13), the coefficient of permeability was found to be inversely related to the effective stress, in accordance with eq. [8]. Again, the k values determined using the different curve fitting techniques were in good agreement. The data is also plotted in Fig. 13 as a function of the water content which can be more readily determined in practice.

$$
\begin{array}{cc}
\mathrm{k}=\mathrm{m}_{\mathrm{v}} \mathrm{c}_{\mathrm{v}} \gamma_{\mathrm{w}} & {[\mathrm{m} / \mathrm{s}]} \\
\log \mathrm{k}=-\left(0.62 \times \log \sigma_{\mathrm{v}}{ }^{\prime}\right)-8.44 & {[\mathrm{~m} / \mathrm{s}]}
\end{array}
$$

where $\mathrm{m}_{\mathrm{v}}$ is the coefficient of volume change corresponding to the load stage; $\mathrm{c}_{\mathrm{v}}$ is the coefficient of primary consolidation; and $\gamma_{\mathrm{w}}$ is the unit weight of water.

The slurry material had a very low permeability $\left(\mathrm{k}=2 \times 10^{-9} \mathrm{~m} / \mathrm{s}\right.$ at $\left.\mathrm{w} \cong 700 \%\right)$. The coefficient of permeability reduced with decreasing water content to $10^{-10} \mathrm{~m} / \mathrm{s}$ at $\mathrm{w} \cong 350 \%$ and $\sigma_{\mathrm{v}}{ }^{\prime} \cong 300$ $\mathrm{kPa}$. Similar values were reported for alum WTS by Wang and Tseng (1993) with the permeability reducing from $8 \times 10^{-8}$ to $3 \times 10^{-10} \mathrm{~m} / \mathrm{s}$ with increasing effective stress from $\sigma_{\mathrm{v}}{ }^{\prime} \cong 2$ to $540 \mathrm{kPa}$. The very low permeability is due to the $\mathrm{Al}(\mathrm{OH})_{3}$ present in the WTS material (Wang et al. 1992), and is also hypothesised to be associated with the microstructure of the sludge flocs (O'Kelly 2008). WTS material contains between 5 and 15\% aluminium by dry weight, and is predominantly amorphous $\mathrm{Al}(\mathrm{OH})_{3}$ which is chemically active, strongly hydrated, and has an exceptionally high affinity for water. The gelatinous flocs of mainly clay-sized organic solids of which the WTS material was composed $(\mathrm{LOI}=57 \%)$ also tended to trap significant volumes of interstitial water within the floc structure.

The rates of secondary compression of the WTS material were quantified in terms of the coefficient of secondary compression $\mathrm{C}_{\mathrm{sec}}$, which was calculated as the change in volumetric strain per 10-fold increase in time after the end of the primary consolidation phase. In this study, the secondary compression phase for the organic sludge was defined to occur for $\bar{U} \geq$ $92 \%$.

The $\mathrm{C}_{\mathrm{sec}}$ values listed in Tables 3 and 4 were computed from the strain versus logarithm of time responses recorded for the: (i) oedometer specimens E and F (Fig. 6); (ii) consolidometer specimen G (Fig. 8); and (iii) triaxial specimens A to D (Fig. 4a). The average degree of consolidation plots in Fig. 10 indicate that at least one complete logarithm cycle of secondary compression data had been recorded for specimen E during the load stages $\sigma_{\mathrm{v}}=50$ to 800 $\mathrm{kPa}$. Two complete logarithm cycles of secondary compression data had been recorded for the load stage at $\sigma_{\mathrm{v}}=800 \mathrm{kPa}$. The same was true for oedometer specimen $\mathrm{F}$, which had a similar effective drainage length. Some extrapolation of the secondary compression data was necessary for the oedometer load stages at $\sigma_{\mathrm{v}} \leq 25 \mathrm{kPa}$, and for the consolidometer and triaxial specimens. The mean of the $\mathrm{C}_{\mathrm{sec}}$ values of 0.01 was high; although typical of extremely plastic, normally consolidated clays. The mean value of the secondary compression index $\mathrm{C}_{\alpha \mathrm{e}}$ (given by eq. [9]) was 0.15 . 
$\mathrm{C}_{\alpha \mathrm{e}}=\mathrm{C}_{\mathrm{sec}}\left(1+\mathrm{e}_{\mathrm{o}}\right)$

where $e_{o}$ is the initial void ratio.

The values of the $\mathrm{C}_{\alpha e} / \mathrm{C}_{\mathrm{c}}$ ratio (introduced by Mesri and co-workers) are also given in Tables 3 and 4. Again, the $\mathrm{C}_{\alpha e} / \mathrm{C}_{\mathrm{c}}$ values of 0.04 to 0.06 are typical of organic clays (Mesri et al. 1995).

\section{Summary and conclusions}

The geotechnical properties of a municipal water-treatment sludge (WTS) derived from the treatment of raw water from an upland catchment of peat over granite bedrock are presented. The study also demonstrates the application of conventional geotechnical laboratory testing and analysis to a difficult, challenging and unconventional geomaterial.

The gelatinous, thixotropic WTS material (which incorporated an alum coagulant and anionic polyelectrolyte coagulant aid) comprised flocs of mainly clay-sized organic solids (gravimetric organic content of about 57\%), and quartz and manganoan calcite minerals. The material was classified as high plasticity organic clay. Standard Proctor compaction over the water content range of 160 to $780 \%$ yielded low bulk and dry density values of 0.95 to 1.10 and 0.12 to 0.36 tonne $/ \mathrm{m}^{3}$, respectively, which were in line with the low specific gravity of solids value of 1.86 . Handling and landfill disposal may prove more difficult above the adhesion limit of $240 \%$ water content due to the tendency of the material to adhere to machine plant. The undrained shear strength of the standard Proctor compacted WTS material was inversely related to its water content on a semi-log plot. The effective stress shear strength parameters were $c^{\prime}=0$ and $\phi^{\prime}=39^{\circ}$, and the value of the shear strength to mean effective confining pressure was between 1.6 and 2.0. The shear resistance was enhanced by the presence of the alum and polyelectrolyte additives in the WTS which deactivated water; aggregated the constituent clay particles into flocs and binded these flocs into clusters.

The saturated WTS material was highly compressible with a primary compression index $\left(\mathrm{C}_{\mathrm{c}}\right)$ of between 2.5 and 3.7 , and a primary compression ratio $\left(\mathrm{C}_{\mathrm{c}}{ }^{*}\right)$ of between 0.20 and 0.28 , for $\sigma_{\mathrm{v}}{ }^{\prime}=3$ to $800 \mathrm{kPa}$. Most of the strain response occurred due to primary consolidation (coefficient of consolidation values of between 0.1 and $0.8 \mathrm{~m}^{2} /$ year). Secondary compression effects were minor, with a mean coefficient of secondary compression $\left(\mathrm{C}_{\mathrm{sec}}\right)$ value of 0.01 ; a mean secondary compression index $\left(\mathrm{C}_{\alpha \mathrm{e}}\right)$ value of 0.15 ; and $\mathrm{C}_{\alpha \mathrm{e}} / \mathrm{C}_{\mathrm{c}}$ values of 0.04 to 0.06 . However, the material had a very low coefficient of permeability which decreased in value from $10^{-9}$ to $10^{-10} \mathrm{~m} / \mathrm{s}$ with increasing effective stress (3 to $300 \mathrm{kPa}$ ), and reducing water content $(\mathrm{w}=700$ to $350 \%$ ). The very low permeability arises due to the significant percentage of amorphous $\mathrm{Al}(\mathrm{OH})_{3}$ (exceptionally high affinity for water) added as a coagulant aid to the slurry material, and is also hypothesised to be associated with the microstructure of the sludge flocs which tends to trap interstitial water.

The geotechnical properties presented can be used to determine the level of dewatering necessary at the treatment works or in drying beds and lagoons to facilitate the safe and efficient handling and disposal of the material at sludge monofills or dedicated deposition areas in municipal landfills, and the provision of an adequate factor of safety against slope instability of WTS deposits. The data can also be used to determine the gain in shear strength due to consolidation, natural air-drying (for example, material that has been used as daily 
cover for a municipal landfill) and curing processes, and the settlement response of the landfilled WTS material.

\section{Acknowledgements}

The author would like to kindly acknowledge the work of Martin Carney, Brian Devaney and Emma Quinn in performing the tests on the WTS material at the Geotechnical Laboratories, Trinity College Dublin. The paper was resubmitted while the author was on sabbatical leave at the Urban Institute Ireland, University College Dublin.

\section{References}

Achari, G., and Joshi, R.C. 1995. Discussion of Permeability behavior of a water treatment sludge. ASCE Geotechnical Engineering. 121(1): 99-101.

BS1377 1990a. Methods of test for soils for civil engineering purposes. British Standards Institution, London.

BS1377 1990b. Methods of test for soils for civil engineering purposes. Part 2: Classification tests. British Standards Institution, London.

BS1377 1990c. Methods of test for soils for civil engineering purposes. Part 5: Compressibility, permeability and durability tests. British Standards Institution, London.

BS1377 1990d. Methods of test for soils for civil engineering purposes. Part 7: Shear strength tests (total stress). British Standards Institution, London.

Casagrande, A., and Fadum, R.E. 1940. Notes on soil testing for engineering purposes. Harvard University Graduate School of Engineering, Publication 8.

Council of European Communities Drinking Water Directive 1998. Quality of water intended for human consumption. Council Directive 98/83/EC. Office for Official Publications of the European Communities.

Geuzens, P., and Dieltjens, W. 1991. Mechanical strength determination of cohesive sludges a Belgian research project on sludge consistency. In Recent developments in sewage sludge processing. Edited by F. Colin, P.J. Newman and Y.J. Puolanne. Elsevier, London, pp. 14-23.

Gibbs, H.J., and Holtz W.G. 1956. Engineering properties of expansive clays. Transactions of the American Society of Civil Engineers, 121(1): paper 2814.

Lim, S., Jeon, W., Lee, J., Lee, K., and Kim, N. 2002. Engineering properties of water/wastewater-treatment sludge modified by hydrated lime, fly ash and loess. Water Research 36: 4177-4184.

Metcalf and Eddy Inc. 1991. Wastewater engineering: treatment, disposal and reuse (3rd ed.) McGraw-Hill, Singapore. 
Mesri, G., Shahien, M., and Feng, T.W. 1995. Compressibility parameters during primary consolidation. In Proceedings of the International Symposium on Compression and Consolidation of Clayey Soils, Hiroshima, vol. 2, pp. 1021-1037.

Mitchell, J.K., and Soga, K. 2005. Fundamentals of soil behavior ( $3^{\text {rd }}$ ed.) Wiley and Sons, New Jersey, USA.

Novak, J.T., and Calkins, D.C. 1975. Sludge dewatering and its physical properties. Journal of American Water Works Association, 67(1): 42-45.

O'Kelly, B.C. 2006. Geotechnical properties of municipal sewage sludge. Geotechnical and Geological Engineering, 24(4): 833-850.

O'Kelly B.C. 2008. Effect of biodegradation on the consolidation properties of a dewatered municipal sewage sludge. Waste Management (revised manuscript submitted 10th July 2007).

Raghu, D., and Hsieh, H-N. 1986. Material properties of water treatment plant sludges. Civil Engineering for Practicing and Design Engineers, 5(11/12): 927-941.

Skempton, A.W. 1954. The pore pressure coefficients A and B. Géotechnique, 4: 143-147.

Taylor, D.W. 1942. Research on consolidation clays. Department of Civil and Sanitation Engineering Report 82. Massachusetts Institute of Technology.

Terzaghi, K. 1943. Theoretical Soil Mechanics. John Wiley and Sons, New York.

Twort, A.C., Ratnayaka, D.D., and Brandt, M.J. 2000. Water Supply (5th ed.) Arnold, London.

Wang, M.C., Hull, J.Q., Jao, M., Dempsey, B.A., and Cornwell, D.A. 1992. Engineering treatment of water treatment sludge. Environmental Engineering, 118(6): 848-864.

Wang, M.C., and Tseng, W. 1993. Permeability behavior of a water treatment sludge. ASCE Geotechnical Engineering, 119(10): 1672-1677.

Wroth, C.P., and Houlsby, G.T. 1985. Soil mechanics - property characterization and analysis procedures. In Proceedings of the Eleventh International Conference on Soil Mechanics and Foundation Engineering, San Francisco, vol. 1, pp. 1-55.

Yang, Y., Tomlinson, D., Kennedy, S., and Zhao, Y.Q. 2006. Dewatered alum sludge: a potential adsorbent for phosphorus removal. Water Science and Technology, 54(5): 207-213. 


\section{List of Tables:}

Table 1. Properties of WTS direct from the treatment works.

Table 2. Summary of consolidation tests.

Note: MI, multiple increment; SI, single increment; $\sigma_{v}$, applied stress; $\sigma_{3}$ ', effective confining pressure; $H$, specimen height.

Table 3. Secondary compression properties (specimens A to D, and G).

Table 4. Secondary compression properties (specimens E and F). 


\section{Legends for (13) Figures:}

Fig. 1. Densities achieved by standard Proctor compaction.

Fig. 2. Deviator stress versus strain plots from UU triaxial compression tests.

Fig. 3. Undrained shear strength versus water content.

(a) Isotropic consolidation.

(b) Deviator stress versus strain.

(c) Pore-water pressure versus strain.

(d) Effective stress path plots.

Fig. 4. CU triaxial compression of specimens A to D.

Fig. 5. Oedometer cell fitted with consolidation cup for pore water pressure measurement.

(a) Logarithm time.

(b) Square-root time.

Fig. 6. Axial strain versus time plots from oedometer tests.

$$
\begin{gathered}
\text { (a) } \sigma_{\mathrm{v}}{ }^{\prime}=3 \text { to } 50 \mathrm{kPa} \text {. } \\
\text { (b) } \sigma_{\mathrm{v}}{ }^{\prime}=100 \text { to } 800 \mathrm{kPa} \text {. }
\end{gathered}
$$

Fig. 7. Pore water pressure response for specimen E (single drained).

Fig. 8. Strain versus time plots for consolidometer specimen G.

Fig. 9. Void ratio versus effective stress plots. Note: solid symbols denote single-increment load tests.
(a) $\sigma_{\mathrm{v}}{ }^{\prime}=3$ to $50 \mathrm{kPa}$.
(b) $\sigma_{\mathrm{v}}{ }^{\prime}=100$ to $800 \mathrm{kPa}$.

Fig. 10. Average degree of consolidation achieved for specimen $\mathrm{E}$.

Fig. 11. Distribution of excess pore water pressure over the height of specimen E.

Fig. 12. Coefficient of consolidation versus effective stress plot.

Fig. 13. Coefficient of permeability and water content plotted against effective stress. 


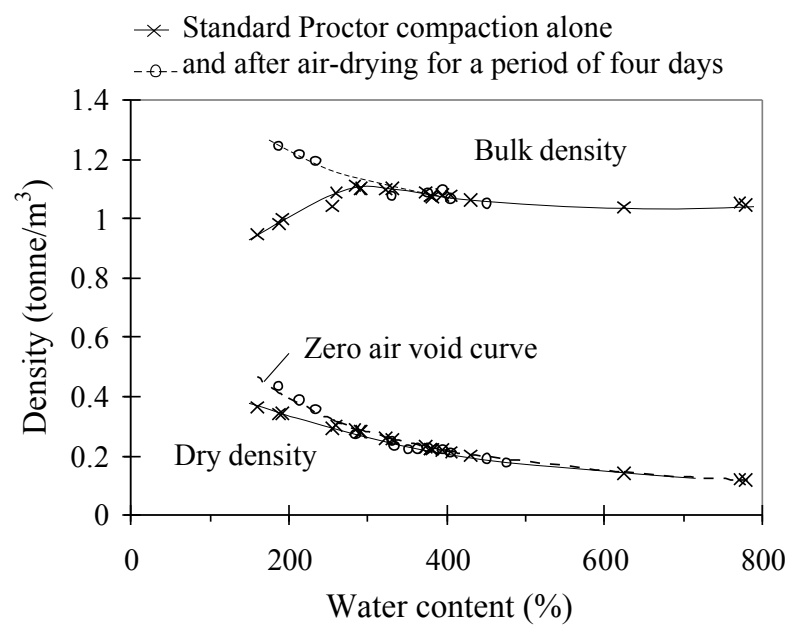

Fig. 1. Densities achieved by standard Proctor compaction.

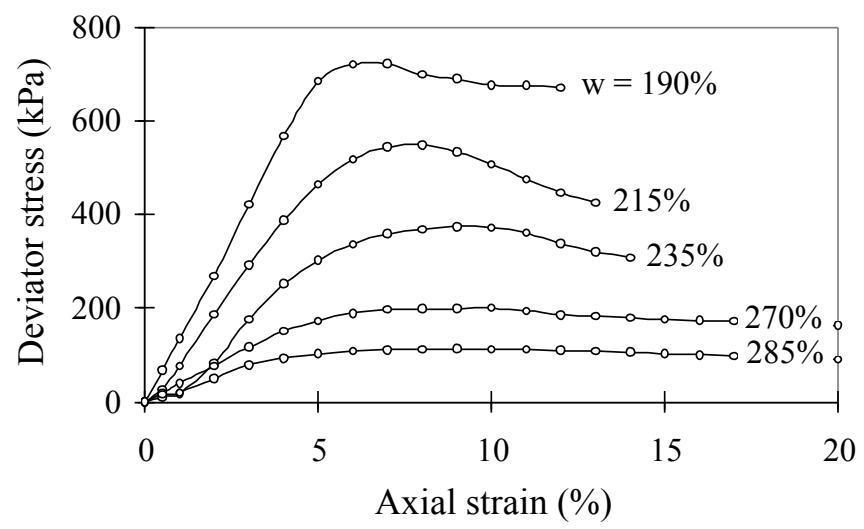

Fig. 2. Deviator stress versus strain plots from UU triaxial compression tests. 


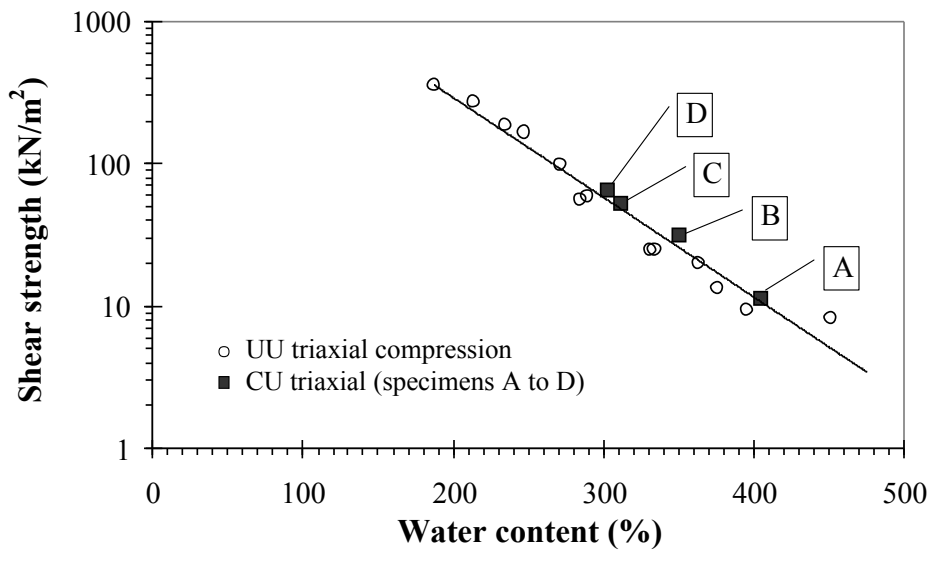

Fig. 3. Undrained shear strength versus water content. 


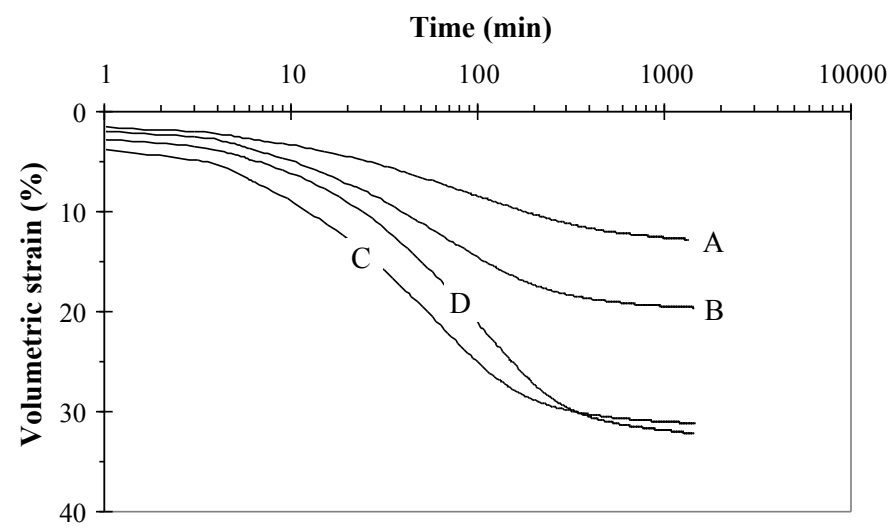

(a) Isotropic consolidation.

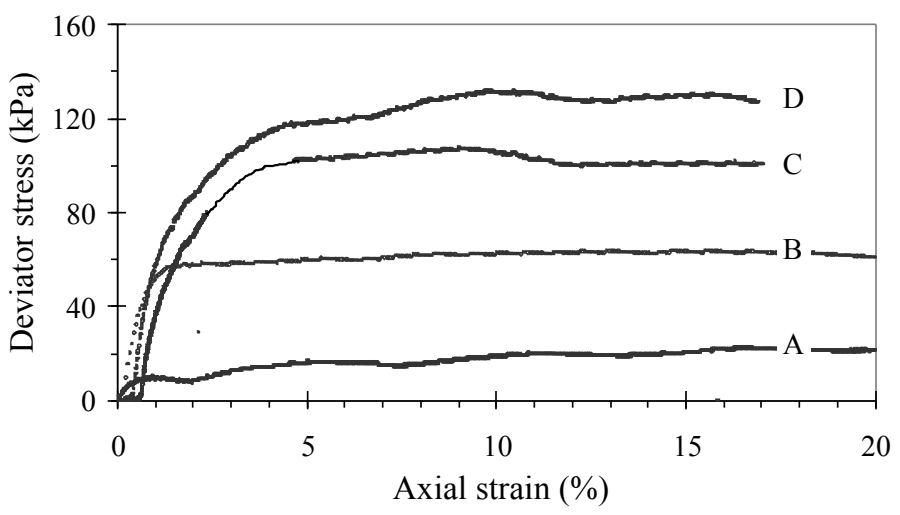

(b) Deviator stress versus strain.

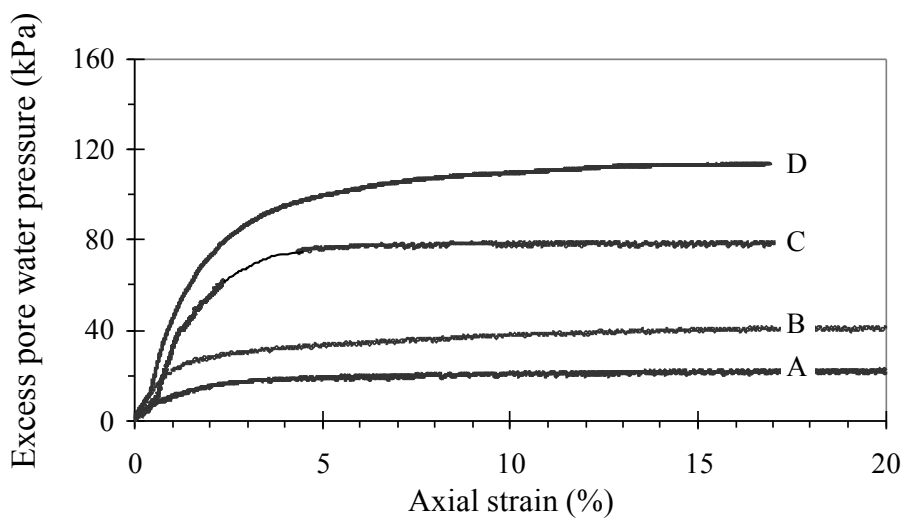

(c) Pore-water pressure versus strain. 


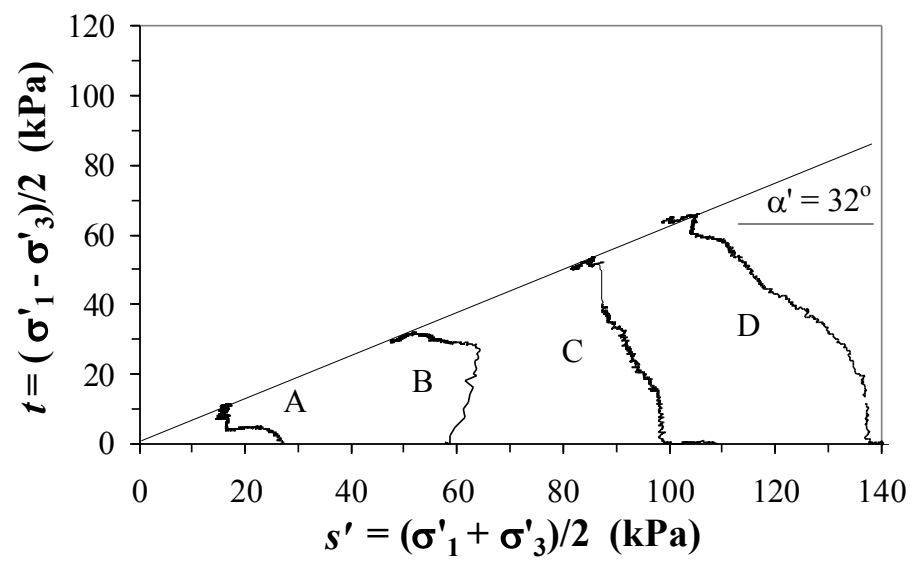

(d) Effective stress path plots.

Fig. 4. CU triaxial compression of specimens A to D.

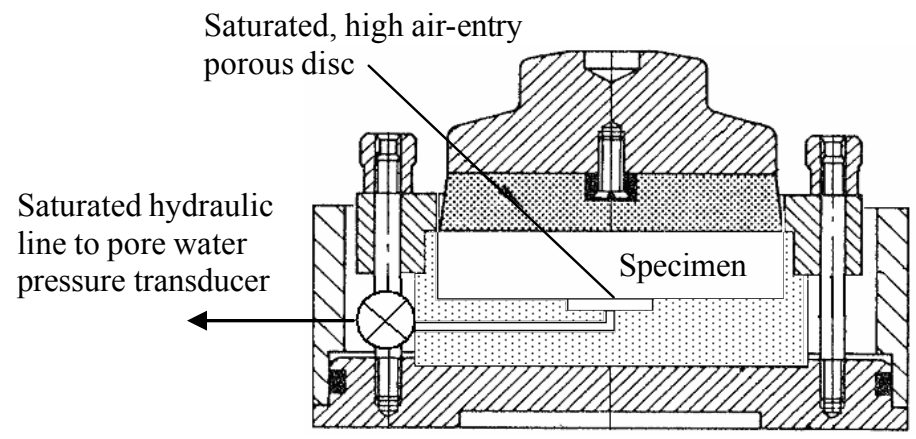

Fig. 5. Oedometer cell fitted with consolidation cup for pore water pressure measurement. 


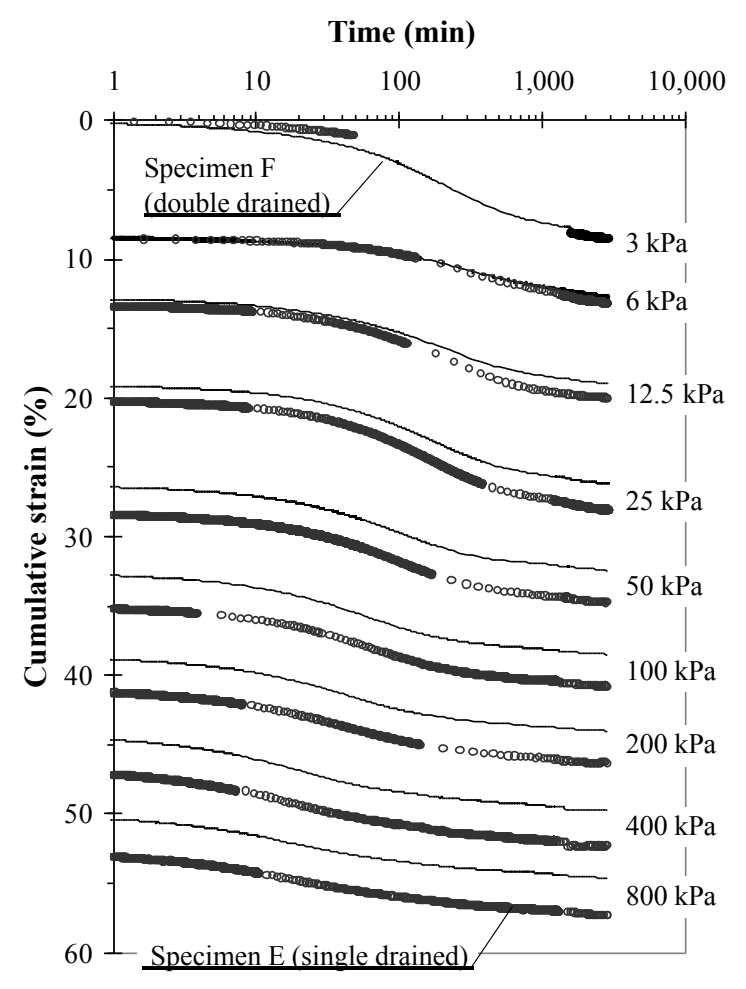

(a) Logarithm time.

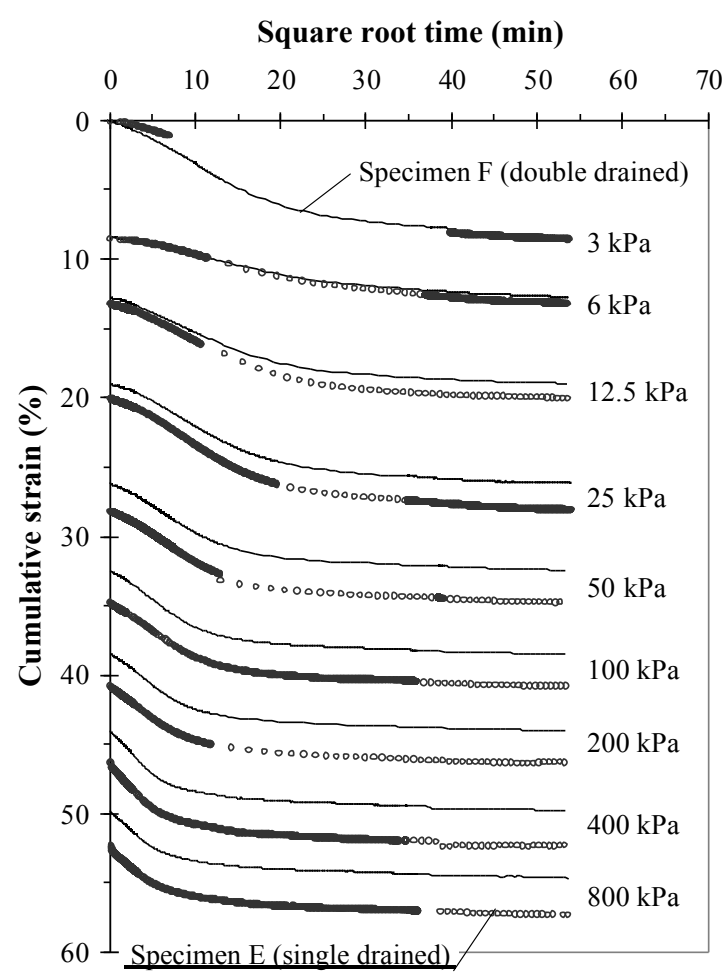

(b) Square-root time.

Fig. 6. Axial strain versus time plots from oedometer tests. 


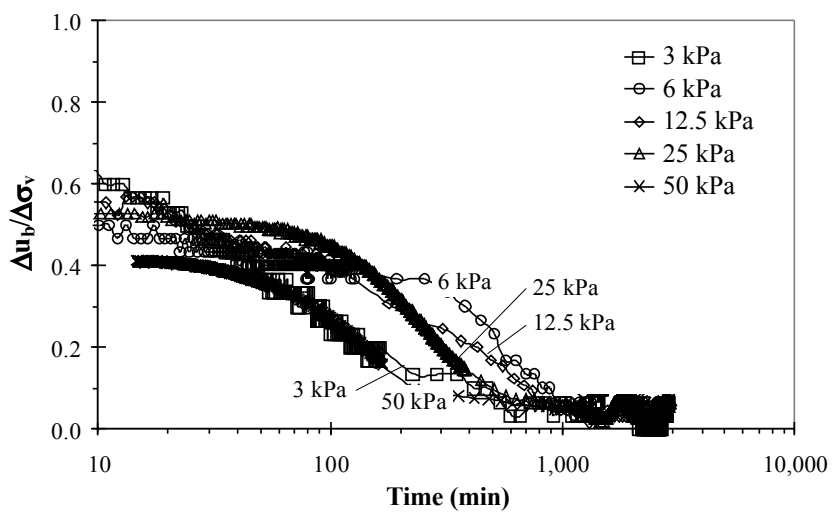

(a) $\sigma_{\mathrm{v}}{ }^{\prime}=3$ to $50 \mathrm{kPa}$.

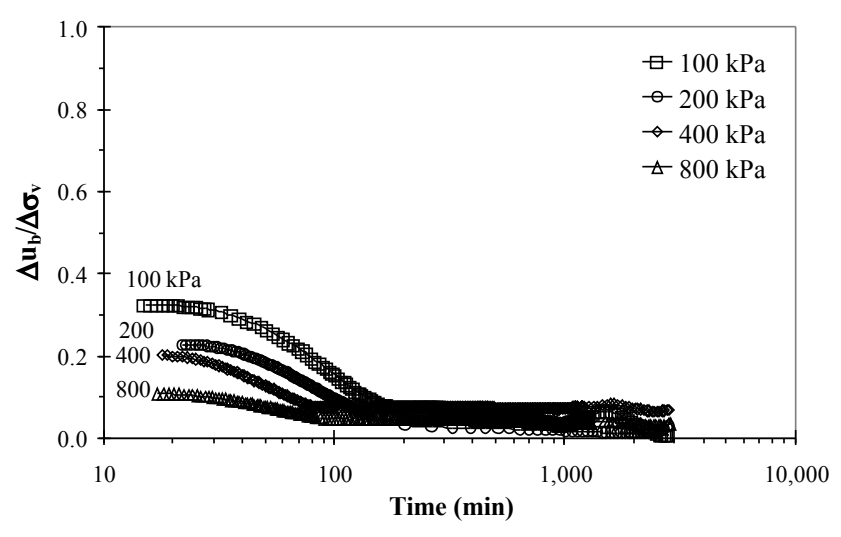

(b) $\sigma_{\mathrm{v}}{ }^{\prime}=100$ to $800 \mathrm{kPa}$.

Fig. 7. Pore water pressure response for specimen E (single drained). 


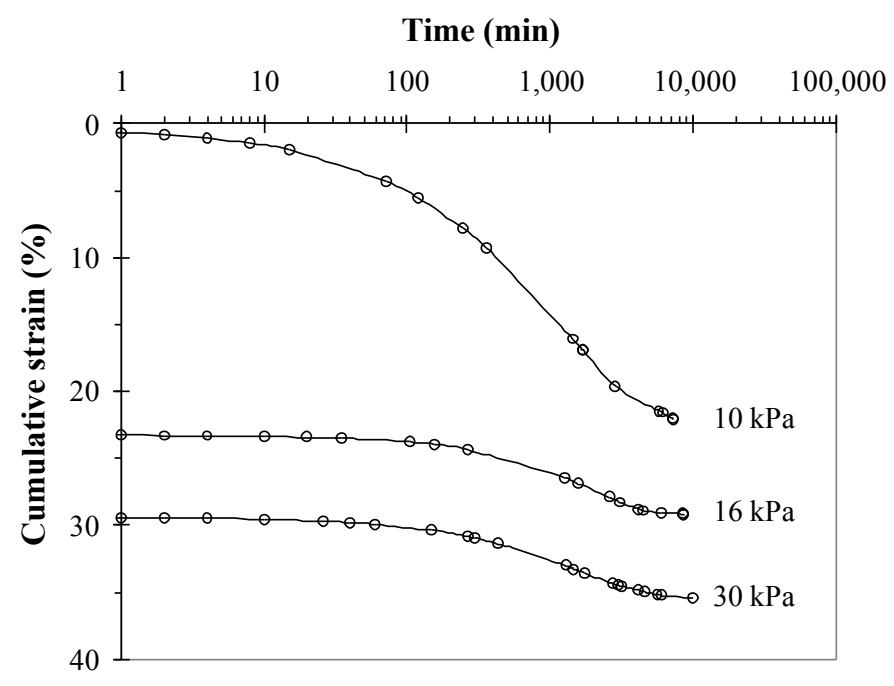

Fig. 8. Strain versus time plots for consolidometer specimen G.

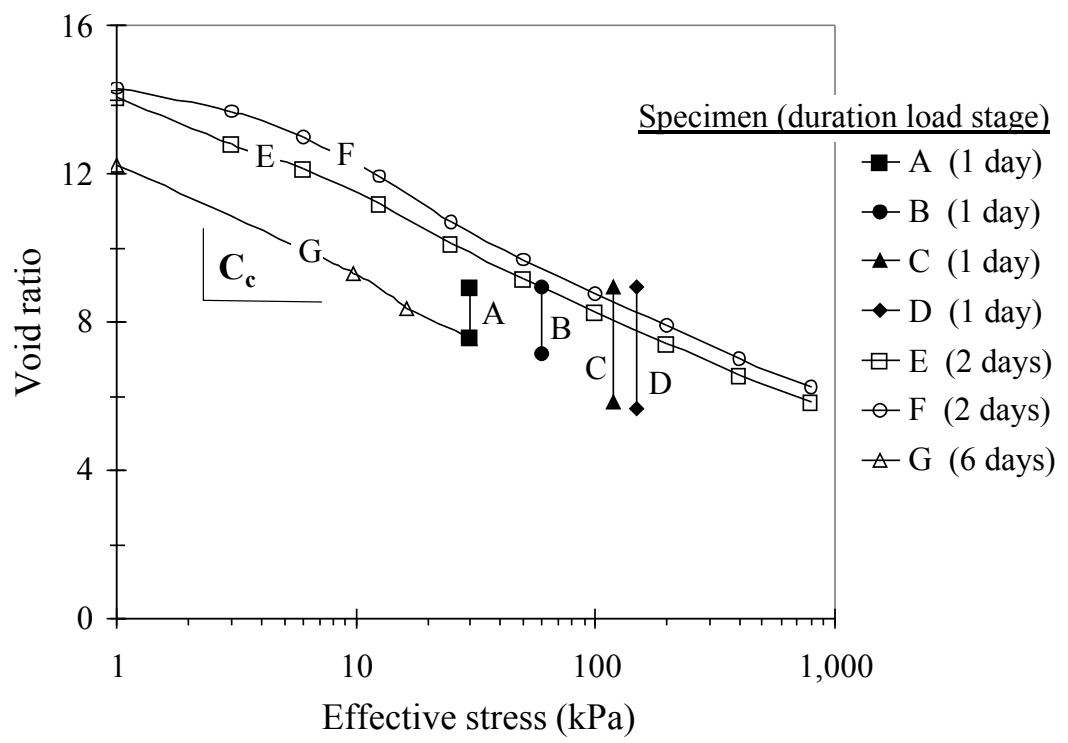

Fig. 9. Void ratio versus effective stress plots. Note: solid symbols denote single-increment load tests. 


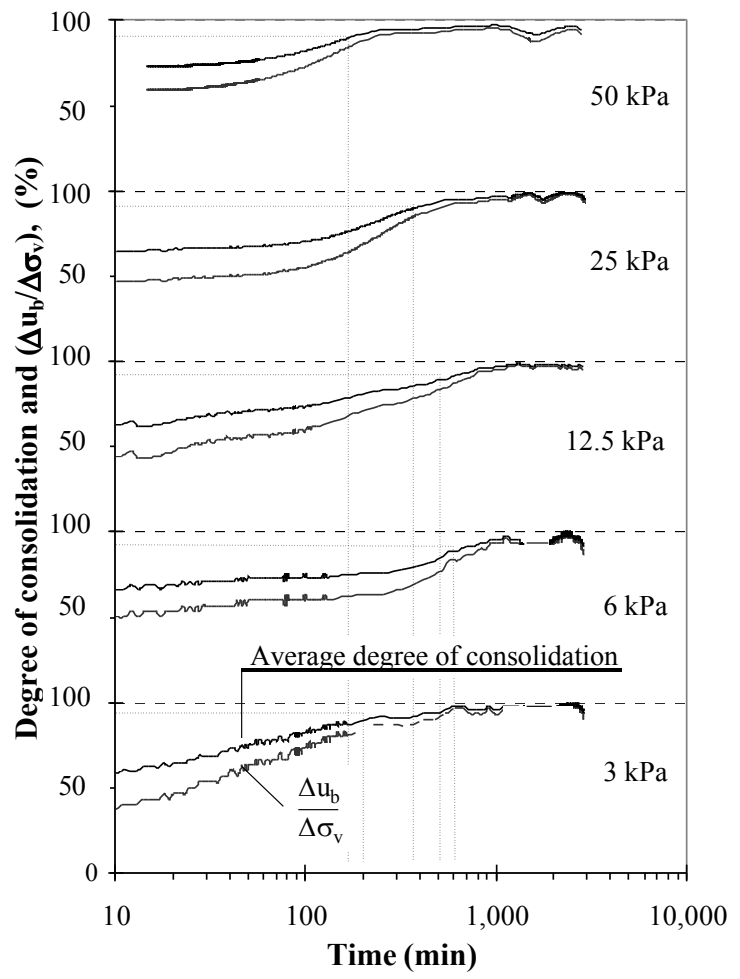

(a) $\sigma_{\mathrm{v}}{ }^{\prime}=3$ to $50 \mathrm{kPa}$.

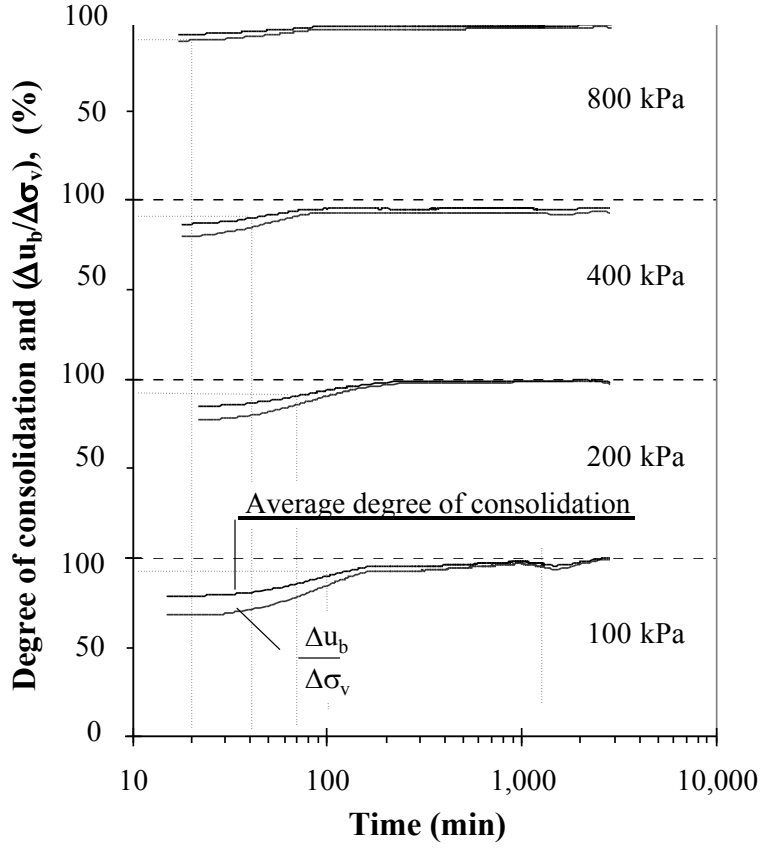

(b) $\sigma_{\mathrm{v}}{ }^{\prime}=100$ to $800 \mathrm{kPa}$.

Fig. 10. Average degree of consolidation achieved for specimen E.

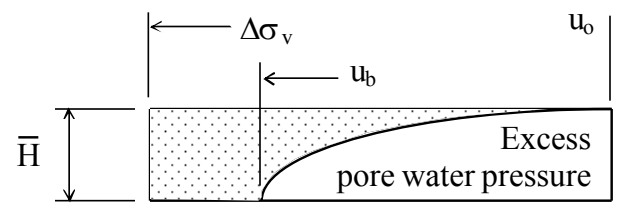

Fig. 11. Distribution of excess pore water pressure over the height of specimen E. 


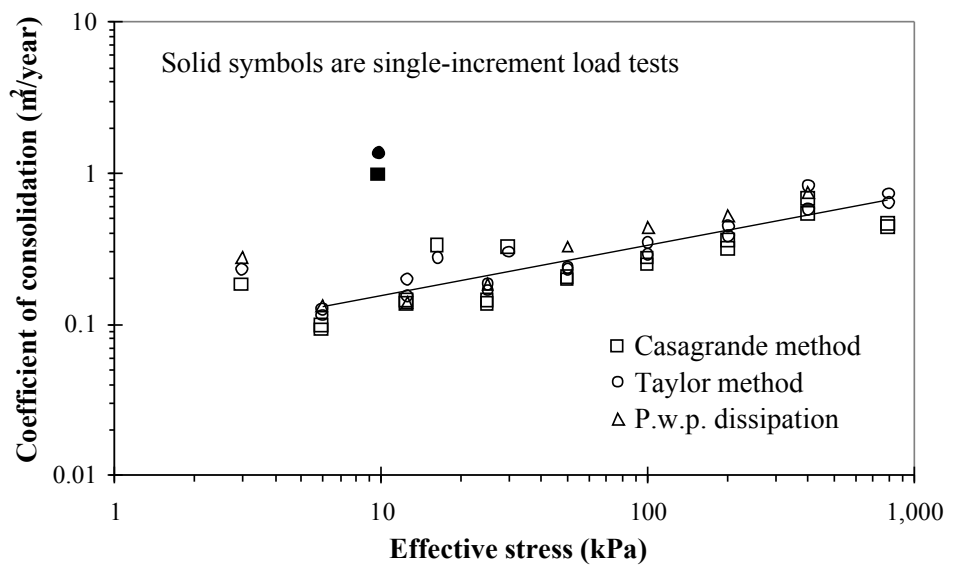

Fig. 12. Coefficient of consolidation versus effective stress plot.

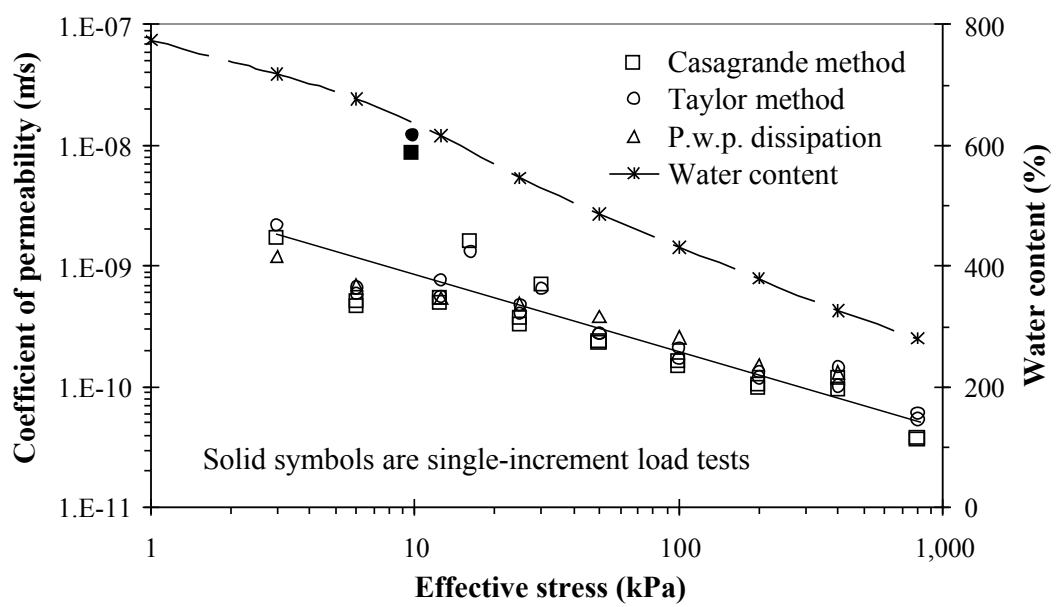

Fig. 13. Coefficient of permeability and water content plotted against effective stress. 


\begin{tabular}{ll} 
Property & Value \\
\hline Liquid limit (\%) & 490 \\
Plastic limit (\%) & 240 \\
Plasticity index (\%) & 250 \\
Specific gravity of solids & 1.86 \\
Loss in dry mass on ignition (\%) & 57 \\
Water content (\%) & 625 \\
Solids content (\%) & 14 \\
Bulk density (tonne $\left./ \mathrm{m}^{3}\right)$ & 10.4 \\
Dry density (tonne $\left./ \mathrm{m}^{3}\right)$ & 1.4 \\
Void ratio & 12.2 \\
Adhesion limit $(\%)$ & 240 \\
Linear shrinkage $(\%)$ & 47 \\
Free swell (volumetric \%) & 35 \\
pH & 8.6 \\
\hline
\end{tabular}

Table 1. Properties of WTS direct from the treatment works.

\begin{tabular}{|c|c|c|c|c|c|}
\hline \multirow[t]{2}{*}{ Specimen } & \multirow[t]{2}{*}{ Consistency } & \multicolumn{2}{|c|}{ Water content (\%) } & \multirow{2}{*}{$\begin{array}{l}\text { Dimensions } \\
(\mathrm{mm})\end{array}$} & \multirow{2}{*}{$\begin{array}{l}\text { Applied stress } \\
(\mathrm{kPa})\end{array}$} \\
\hline & & Initial & Final & & \\
\hline \multicolumn{6}{|c|}{ Isotropic triaxial } \\
\hline A & Very soft & 475 & 405 & \multirow{4}{*}{$\begin{array}{l}38.0 \text { dia. } \times 76.0 \mathrm{H} \\
\text { (all around drainage) }\end{array}$} & SI: $\sigma_{3}{ }^{\prime}=30$ \\
\hline B & Very soft & 475 & 350 & & SI: $\sigma_{3}{ }^{\prime}=60$ \\
\hline $\mathrm{C}$ & Very soft & 475 & 310 & & SI: $\sigma_{3}{ }^{\prime}=120$ \\
\hline $\mathrm{D}$ & Very soft & 475 & 300 & & SI: $\sigma_{3}{ }^{\prime}=150$ \\
\hline \multicolumn{6}{|c|}{ Oedometer } \\
\hline $\mathrm{E}$ & Slurry & 780 & 280 & $\begin{array}{l}76.2 \text { dia. } x 14.8 \mathrm{H} \\
\text { (one-way drainage) }\end{array}$ & MI: $\sigma_{v}=3-800$ \\
\hline F & Slurry & 770 & 280 & $\begin{array}{l}76.2 \text { dia. } x 30.0 \mathrm{H} \\
\text { (two-way drainage) }\end{array}$ & MI: $\sigma_{\mathrm{v}}=3-800$ \\
\hline \multicolumn{6}{|c|}{ Consoliometer } \\
\hline G & Slurry & 625 & 475 & $\begin{array}{l}152 \text { dia. } \times 139 \mathrm{H} \\
\text { (two-way drainage) }\end{array}$ & MI: $\sigma_{v}=10-30$ \\
\hline
\end{tabular}

Table 2. Summary of consolidation tests. Note: MI, multiple increment; SI, single increment; $\sigma_{\mathrm{v}}$, applied stress; $\sigma_{3}{ }^{\prime}$, effective confining pressure; $H$, specimen height. 


\begin{tabular}{lllll}
\hline Specimen & $\begin{array}{l}\text { Applied } \\
\text { stress }(\mathrm{kPa})\end{array}$ & $\mathrm{C}_{\mathrm{sec}}$ & $\mathrm{C}_{\alpha \mathrm{e}}$ & $\mathrm{C}_{\alpha \mathrm{e}} / \mathrm{C}_{\mathrm{c}}$ \\
\hline $\mathrm{G}$ & 10 & 0.055 & 0.73 & 0.21 \\
$\mathrm{G}$ & 16 & 0.008 & 0.10 & 0.03 \\
$\mathrm{G}$ & 30 & 0.008 & 0.10 & 0.03 \\
$\mathrm{~A}$ & 30 & 0.013 & 0.13 & 0.05 \\
$\mathrm{~B}$ & 60 & 0.012 & 0.12 & 0.04 \\
$\mathrm{C}$ & 120 & 0.011 & 0.11 & 0.04 \\
$\mathrm{D}$ & 150 & 0.017 & 0.17 & 0.06 \\
\hline
\end{tabular}

Table 3. Secondary compression properties (specimens A to D, and G).

\begin{tabular}{|c|c|c|c|c|c|c|}
\hline \multirow{2}{*}{$\begin{array}{l}\text { Applied } \\
\text { stress }(\mathrm{kPa})\end{array}$} & \multicolumn{3}{|c|}{ Specimen E } & \multicolumn{3}{|c|}{ Specimen F } \\
\hline & $\mathrm{C}_{\mathrm{sec}}$ & $\mathrm{C}_{\alpha \mathrm{e}}$ & $\mathrm{C}_{\alpha \mathrm{e}} / \mathrm{C}_{\mathrm{c}}$ & $\mathrm{C}_{\mathrm{sec}}$ & $\mathrm{C}_{\alpha \mathrm{e}}$ & $\mathrm{C}_{\alpha \mathrm{e}} / \mathrm{C}_{\mathrm{c}}$ \\
\hline 3 & - & - & - & 0.017 & 0.25 & 0.11 \\
\hline 6 & 0.018 & 0.28 & 0.10 & 0.012 & 0.18 & 0.07 \\
\hline 12.5 & 0.010 & 0.15 & 0.04 & 0.011 & 0.17 & 0.05 \\
\hline 25 & 0.014 & 0.21 & 0.06 & 0.014 & 0.20 & 0.06 \\
\hline 50 & 0.010 & 0.16 & 0.05 & 0.010 & 0.14 & 0.05 \\
\hline 100 & 0.009 & 0.14 & 0.05 & 0.008 & 0.11 & 0.04 \\
\hline 200 & 0.009 & 0.14 & 0.05 & 0.008 & 0.12 & 0.04 \\
\hline 400 & 0.009 & 0.13 & 0.04 & 0.008 & 0.12 & 0.04 \\
\hline 800 & 0.007 & 0.11 & 0.05 & 0.007 & 0.10 & 0.05 \\
\hline
\end{tabular}

Table 4. Secondary compression properties (specimens E and F). 